\title{
The Company They Keep
}

\section{Founders' Models for Organizing New Firms}

\author{
M. DIANE BURTON
}

In starting a company, entrepreneurs pursue courses of action that, intentionally or unintentionally, embody different assumptions about the nature of work, the nature of people, the appropriate bases for attaching people to organizations, and the best methods for controlling and coordinating work. Such differing premises lead entrepreneurs to build different types of firms, particularly with respect to the employment relationship. Early employmentrelated choices - which crystallize organizational culture, authority relations, and routines concerning work - are among the most difficult to undo (Hannan and Freeman 1984). Furthermore, there is ample empirical evidence demonstrating that decisions about whom to employ and how to organize their work is related to the earliest viability of a firm (Boeker 1988; Cooper, Gimeno-Gascon, and Woo 1994; Eisenhardt and Schoonhoven 1990; MacMillan, Siegel, and Subba Narasimha 1985). Yet despite consensus that these early employment-related choices are important, there has been little systematic research on the factors that influence founders' decisions. Instead, most research on how founders launch new ventures has emphasized the entrepreneurs' strategies for products, markets, technology, operations, and finance

This research was supported by the Division of Research of Harvard Business School, the Stanford Graduate School of Business (particularly the Center for Entrepreneurial Studies), and the Alfred P. Sloan Foundation. I am deeply indebted to Mike Hannan and Jim Baron for support of many kinds. I also benefited greatly from discussions with and comments from Karen Aschaffenburg, Nitin Nohria, Mike Tushman, Marc Ventresca, and Stephanie Woerner. 
(e.g., Romanelli 1989a). Yet a new venture's capacity to recruit the appropriate people and build an effective organization around them arguably has as much if not more to do with ultimate success (Stinchcombe 1965).

In making organizational and employment-related decisions, founders necessarily rely on a mental model of the correct and appropriate ways to organize and to manage (DiMaggio 1997; Fligstein 1990; Karpik 1978). These models are culturally and historically situated prescriptions for organizing and managing (Barley and Kunda 1992; Guillen 1994). Organizational theory provides a strong prediction that, taking into account the environmental conditions facing the firm (Pfeffer and Salancik 1978) and the technical demands of the task (Thompson 1967; Woodward 1965), there will be a dominant model, especially within the boundaries of a particular industry (DiMaggio and Powell 1983). Interestingly, despite this prediction, observers have found different employment models across seemingly similar firms (Applebaum and Batt 1994; Henderson and Cockburn 1994; Kochan, Katz, and McKersie 1992). The question of what accounts for this heterogeneity is largely unanswered (Romanelli 1991). An important first step is to understand different mental models and their sources.

Although extant theory implies that organizations founded at particular times in particular industries tend to exhibit similar employment models, differences in founders' educational and employment experiences may produce diversity in their understanding of what the normative employment models are. Novel models may arise by accident, invented by those who are either inexperienced or disconnected or both (March and Olsen 1976; Hannan and Freeman 1989). Alternatively, founders might intentionally deviate from the normative models because of unhappy experiences. They may also strategically avoid such models out of a belief than an atypical employment model may lead to competitive advantages. Thus, novel models may arise when leaders believe that they can prosper by deliberately choosing a distinctive approach to organizing and managing (DiMaggio 1988; Fligstein 1987; Schein 1983). Without a clear understanding of how variation in employment models arises, we cannot begin to understand how particular choices may relate to the development of the firm or to its performance.

This chapter examines the employment models founders use as they begin to construct new firms. The empirical setting is a sample of emerging high- 
technology firms in Silicon Valley. This chapter focuses on two questions: (1) Why are new firms founded under different conceptual models? and (2) What are the factors that lead a founding team to espouse a particular employment model?

Nascent organizations, start-ups, are ideal subjects for studying variations in employment models. The founding team members must immediately make a series of staffing and organization-building decisions that necessarily embody the employment relationship. Moreover, in a new firm, the choices are not limited by prior decisions nor do they build on existing policies; instead, the decisions arise directly from the founders' mental models. The initial employment model and the organizational strategy are simultaneously set as a firm is founded; thus, one can examine contemporaneous associations without concern for causality. Finally, because new firms have not yet established either a reputation or a track record, they depend on external ties to provide both resources and legitimacy (Starr and Macmillan 1990). Because of this dependency, new firms may be especially receptive to external influences that impose normative models (Scott 1995).

\section{EMPLOYMENT MODELS IN START-UPS}

The data for this chapter come from information collected as part of the Stanford Project on Emerging Companies (SPEC). ${ }^{1}$ SPEC is a panel study examining the founding conditions, the evolution of employment practices, organizational designs, and business strategies, and the longer-term consequences of early organization building in a sample of 173 young high-technology firms in Silicon Valley. The firms in the study were founded between 1982 and 1994 and had at least 10 employees at the time of sampling in 1994-95.

The design of the SPEC study deliberately narrows some of the possible sources of variation in founders' models. For example, focusing on firms in a single region and sector of economic activity necessarily controls for labor mar-

1. The description draws heavily from published research papers by M. Diane Burton, James Baron, Michael Hannan, and others affiliated with the Stanford Project on Emerging Companies (SPEC). 
ket and environmental conditions, as well as for some of the institutional influences asserted to shape organizations. There are other reasons to expect a great deal of homogeneity in organizational models among young Silicon Valley technology companies. Compared with the economy as a whole, the tasks of high-technology companies are relatively similar. For the most part, firms in Silicon Valley are subject to the same state and regional legal and regulatory environment. The accessibility of capital and the tightly interconnected infrastructure of service providers such as lawyers, headhunters, accountants, and consultants that fuel the start-up creation process should, in theory, create relatively standardized organizations (cf. Suchman 1994a). All of the firms are in rapidly changing environments, and all of them are critically dependent on technical talent, a resource that tends to be in short supply. Both employees and founders in Silicon Valley are highly mobile (Rogers and Larsen 1984; Saxenian 1994).

Prior SPEC research has demonstrated that there is heterogeneity in founders' employment models. Researchers have identified archetypal employment models that are associated with distinctive human resources practices (Baron, Burton, and Hannan 1996) and that predict subsequent organizational development, including the timing of an initial public stock offering, the transition to a non-founder CEO (Hannan, Burton, and Baron 1996), the amount of managerial and administrative overhead (Baron, Hannan, and Burton 1999), and the extent of bureaucratization (Baron, Burton, and Hannan 1999). This prior research documents that the employment models are real: they are empirically observable and have measurable and predictable consequences for firms. This chapter assesses whether there is a dominant model within particular industry segments and attempts to identify the factors that account for conformity to or deviance from what may be normatively prescribed.

The primary data for this chapter come from open-ended interviews that I and several research associates conducted with founders. These interviews typically lasted 60 minutes, during which time the founder was first asked to describe the impetus for forming a company, how the founding team was put together, and the planned source of competitive advantage. Each founder was then asked whether he or she had "an organizational model or blueprint in mind" when he or she founded the company. Founders described models ret- 
rospectively in the context of a semi-structured interview in which the questions and probes were open-ended and were part of an informal dialogue.

Detailed qualitative analysis of the transcripts revealed three recurring dimensions along which founders' descriptions varied: (1) the nature of the employees' attachment to the firm, (2) the basis for selecting new employees, and (3) the mode of coordinating and controlling work (for additional details, see Burton 1995).

Attachment. Founders articulated three different bases of employees' attachment: love, work, and money. Some founders envisioned creating a strong family-like feeling and an intense emotional bond with the workforce that would inspire superior effort and help retain highly sought employees. In these firms, what binds the employee is a sense of personal belonging and identification with the company that is labeled love. Other founders believed that the primary motivator for their employees was the desire to work at the technological frontier. These founders relied on providing interesting and challenging work as the basis for attracting, motivating, and perhaps retaining employees. Finally, other founders stated that they regarded the employment relationship as a simple exchange of labor for money.

Selection. Founders described three bases for selecting employees: skills, potential, and fit. Some founders seemed to think of the firm as a bundle of tasks and sought employees with the requisite skills and experience needed to accomplish some immediate tasks. Other founders focused less on immediate and well-defined tasks than on a series of projects, often not yet even envisioned, through which employees would move over time. Accordingly, they focused on long-term potential. Finally, another group of founders focused primarily on values or cultural fit and placed heavy emphasis on how a prospective hire would connect with others in the organization.

Mode of coordination and control. The most common blueprint for controlling and coordinating work involved extensive reliance on informal control through peers or the organizational culture. Other founders appeared to take for granted the fact that workers were committed to excellence in their work and could perform at high levels because they had been professionally socialized to do so. Professional control emphasizes autonomy and independence, rather than inculturation, and founders using this approach tended to recruit high-potential individuals from elite institutions. A third group of 
founders espoused a more traditional view of control as being embedded in formal procedures and systems. Finally, some founders stated that they intended to control and coordinate work personally, by direct oversight, reminiscent of the simple control paradigm that Edwards (1979) identified as characteristic of small capitalist firms in the late-nineteenth and early twentieth century.

Founders' employment models are made up of one of three possible variants of both attachment and selection and one of four possible variants of control, yielding the potential for $3 \times 3 \times 4=36$ unique employment models. But iterative inductive analyses of the interview transcripts suggested that founders drew on a small number of salient cultural institutions-universities and research laboratories, project teams, traditional hierarchies, and communities-to describe their models, and many of the observations in the SPEC sample cluster into five of the 36 cells, which neatly correspond to the cultural institutions and account for 57\% (88 of 154) of the ventures. ${ }^{2}$ Table 2.1 shows these basic archetypal models, which are here labeled engineering, star, commitment, bureaucracy, and autocracy, with their corresponding dimensions and prevalence in the sample.

Each of the archetypal models exemplifies a well-understood mode of organizing. The engineering model, which involves attachment through challenging work, peer-group control, and selection based on specific task abilities, resembles a task-focused project team. The star model resembles the organizing mode of science and academia, wherein attachment derives from challenging work, there is a reliance on autonomy and professional control, and personnel are selected based on their long-term potential. The commitment model is family-like and relies on emotional attachments of employees to the organization, selection based on cultural fit, and peer-group control. The bureaucracy model is a modern, rationalized, organization and involves attachment based on providing challenging work and/or opportunities for development, selecting individuals based on their qualifications for a particular role, and relying on formalized control. Finally, the autocracy model is reminiscent

2. We were able to code the component dimensions of the founding employment model for 154 of the 173 firms. In some cases we were unable to interview a founder. In other cases the transcripts lacked sufficient detail to code reliably all three dimensions (attachment, selection, and control). 
Table 2.1

Five Archetypal Employment Models Based on Three Dimensions

\begin{tabular}{|c|c|c|c|c|}
\hline \multicolumn{3}{|c|}{ Dimensions } & Employment Model & Percent of Firms \\
\hline ATTACHMENT & SELECTION & $\begin{array}{l}\text { OORDINATION/ } \\
\text { CONTROL }\end{array}$ & & \\
\hline Work & Potential & Professional & Star & $8.4 \%$ \\
\hline Work & Skills & Peer/cultural & Engineering & $32.5 \%$ \\
\hline Love & Fit & Peer/cultural & Commitment & $7.1 \%$ \\
\hline Work & Skills & Formal & Bureaucracy & $5.2 \%$ \\
\hline Money & Skills & Direct & Autocracy & $3.9 \%$ \\
\hline
\end{tabular}

of turn-of-the-century factories, in which employment is premised on purely monetary motivations, control and coordination are achieved through close personal oversight, and employees are selected based on their ability to perform prespecified tasks.

The remaining $43 \%$ of the sample - those firms that are located in one of the 31 cells other than the five cells representing the basic types-can be characterized according to their distance from the archetypes by counting the number of dimensions that would need to change in order to transform a firm in a given cell into a basic model. For example, a firm with money as the basis of attachment, skill-oriented selection criteria, and formal control systems (money, skill, formal control) would be three dimensions from a commitment firm (love, fit, normative control), two dimensions from an engineering firm (work, skill, normative control), but only one dimension from either a bureaucracy (work, skill, formal control) or an autocracy (money, skill, direct control).

Under this formulation, one can argue that virtually all of the firms in the SPEC sample are conceptually close to at least one of the five basic models. Eighty-eight of the 154 firms (57\%) are accounted for by the basic types. Another 64 firms (42\%) are within a single dimension of at least one basic type of employment model. Within this group, it is useful to differentiate hybrid models, those that are one dimension from two or more basic types ( 47 firms, or $31 \%$, use hybrid models), and quasi models, those that are one dimension from a single basic type ( 15 firms, or $10 \%$, have quasi models). Only two firms out of $154(1 \%)$ are aberrant or incongruent (two dimensions away from a basic employment model). Table 2.2 presents a diagram of all 36 cells indi- 
cating the distance of each model from basic employment models as well as counts of the number of firms in each cell.

From the numbers in Table 2.2, one might conclude that the engineering model is dominant in Silicon Valley-nearly one-third of the firms exhibit basic engineering models and an additional third (50 of 154) are within a single dimension of the engineering model. But what of the remaining third of the firms? A closer examination of the firms' environment or strategy may account for such model variations without having to take into account the unique biography of each firm, as Kimberly and Bouchikhi (1995) suggested, because the SPEC sample design controls for history and geography. The most salient environmental feature is the industry, and although all of the SPEC firms are technology related, they operate in different industries that are subject to different regulatory environments and face different domestic and international competition. Different industries may also have different norms and cultures. The firms were coded into broad industry categories that capture the major sources of environmental variation that they faced: computer related, semiconductor, networking and telecommunications, medical related, research, and manufacturing. Within the SPEC sample, there is a strong association between the founding employment model and the firm's industry, as shown in Table 2.3.

Among the 88 firms that were founded with a basic model, there appears to be a clear dominant archetype. For example, at least one-third of the firms in the electronics industries - computers (37.5\%), semiconductors (37.5\%), and networking (33.3\%) - were founded with the engineering model. Over $40 \%$ of the firms in the medical and research industries were founded under the star model, which resembles the universities and laboratories from which much of their talent is recruited. Among manufacturing firms the only archetype exhibited in the SPEC sample is the commitment model. In subsequent analyses (except one assessing the effect of strategy), industries that have the same dominant industry model are combined and relabeled, resulting in three

3. These industry categories are rather coarse. For example, the medical-related industry category includes both medical device companies and biotechnology companies. For purposes of characterizing the environment, both types of firms are subject to regulation by the Food and Drug Administration. In this way, they are similar to one another yet distinct from other electronics and high-tech companies in the sample. 
Table 2.2

Firm Classification According to a Three-Way Crosstabulation of Employment Model Dimensions (including cell counts)

\begin{tabular}{|c|c|c|c|c|c|}
\hline \multirow[t]{2}{*}{ Control } & \multirow[t]{2}{*}{ Selection } & \multicolumn{4}{|c|}{ Attachment } \\
\hline & & LOVE & WORK & MONEY & TOTAL \\
\hline \multirow[t]{11}{*}{ Professional } & Skills & 0 & 6 & 2 & 8 \\
\hline & & Unclassified & Hybrid & Quasi & \\
\hline & & & Star/ & Autocracy & \\
\hline & & & Engineering/ & & \\
\hline & & & Bureaucracy & & \\
\hline & Potential & 0 & 13 & 0 & 13 \\
\hline & & Quasi & Archetypal & Quasi & \\
\hline & & Star & Star & Star & \\
\hline & Fit & 0 & 1 & 0 & 1 \\
\hline & & Quasi & Quasi & Unclassified & \\
\hline & & Commitment & Star & & \\
\hline \multirow[t]{8}{*}{ Normative } & Skills & 9 & 50 & 6 & 65 \\
\hline & & Hybrid & Archetypal & Hybrid & \\
\hline & & $\begin{array}{c}\text { Commitment/ } \\
\text { Engineering }\end{array}$ & Engineering & $\begin{array}{l}\text { Engineering/ } \\
\text { Autocracy }\end{array}$ & \\
\hline & Potential & 2 & 8 & 0 & 10 \\
\hline & & $\begin{array}{c}\text { Quasi } \\
\text { Commitment }\end{array}$ & $\begin{array}{c}\text { Hybrid } \\
\text { Star/ } \\
\text { Engineering }\end{array}$ & Unclassified & \\
\hline & Fit & 11 & 9 & 2 & 22 \\
\hline & & Archetypal & Hybrid & Quasi & \\
\hline & & Commitment & $\begin{array}{l}\text { Commitment/ } \\
\text { Engineering }\end{array}$ & Commitment & \\
\hline \multirow[t]{9}{*}{ Formal } & Skills & 0 & 8 & 4 & 12 \\
\hline & & Quasi & Archetypal & Hybrid & \\
\hline & & Bureaucracy & Bureaucracy & $\begin{array}{l}\text { Bureaucracy/ } \\
\text { Autocracy }\end{array}$ & \\
\hline & Potential & 0 & 1 & 0 & 1 \\
\hline & & Unclassified & Hybrid & Unclassified & \\
\hline & & & Star/Bureaucracy & & \\
\hline & Fit & 1 & 1 & 2 & 4 \\
\hline & & Quasi & Quasi & Unclassified & \\
\hline & & Commitment & Bureaucracy & & \\
\hline \multirow[t]{11}{*}{ Direct } & Skills & 2 & 4 & 6 & 12 \\
\hline & & Quasi & Hybrid & Archetypal & \\
\hline & & Autocracy & Engineer/ & Autocracy & \\
\hline & & & Bureaucracy/ & & \\
\hline & & & Autocracy & & \\
\hline & Potential & 0 & 1 & 0 & 1 \\
\hline & & Unclassified & Quasi & Quasi & \\
\hline & & & Star & Autocracy & \\
\hline & Fit & 5 & 0 & 0 & 5 \\
\hline & & Quasi & Unclassified & Quasi & \\
\hline & & Commitment & & Autocracy & \\
\hline \multicolumn{2}{|c|}{ TOTAL AT FOUNDING } & 29 & 103 & 22 & 154 \\
\hline
\end{tabular}


Table 2.3

Industry and Archetype Model Association

(cell counts and row percentages)

\begin{tabular}{lccccccc}
\hline & Engineering & Star & Commitment & Autocracy & Bureaucracy & Other & Total \\
\hline Computer-related & 27 & 2 & 5 & 3 & 4 & 31 & 72 \\
& $(37.5 \%)$ & $(2.8 \%)$ & $(6.9 \%)$ & $(4.2 \%)$ & $(5.6 \%)$ & $(43.1 \%)$ & \\
Semiconductor & 6 & 0 & 2 & 1 & 1 & 6 & 16 \\
& $(37.5 \%)$ & $(0.0 \%)$ & $(12.5 \%)$ & $(6.3 \%)$ & $(6.3 \%)$ & $(37.5 \%)$ & \\
Networking and & & & & & & & \\
Telecommunications & 11 & 0 & 2 & 2 & 2 & 16 & 33 \\
& $(33.3 \%)$ & $(0.0 \%)$ & $(6.1 \%)$ & $(6.1 \%)$ & $(6.1 \%)$ & $(8.5 \%)$ & \\
Medical related & 5 & 9 & 0 & 0 & 1 & 7 & 22 \\
& $(22.7 \%)$ & $(40.9 \%)$ & $(0.0 \%)$ & $(0.0 \%)$ & $(4.5 \%)$ & $(31.8 \%)$ & \\
Research & 1 & 2 & 0 & 0 & 0 & 1 & 4 \\
& $(25.0 \%)$ & $(50.0 \%)$ & $(0.0 \%)$ & $(0.0 \%)$ & $(0.0 \%)$ & $(25.0 \%)$ & \\
Manufacturing & 0 & 0 & 2 & 0 & 0 & 5 & 7 \\
& $(0.0 \%)$ & $(0.0 \%)$ & $(28.6 \%)$ & $(0.0 \%)$ & $(0.0 \%)$ & $(71.4 \%)$ & \\
TOTAL & 50 & 13 & 11 & 6 & 8 & 66 & 154 \\
& $(30.8 \%)$ & $(8.4 \%)$ & $(7.1 \%)$ & $(3.9 \%)$ & $(5.2 \%)$ & $(42.9 \%)$ & \\
\hline
\end{tabular}

NOTE: Pearson chi-square $=59.08$, d.f. $=25, p=.000$

broad industry categories: (1) the electronics industry (computers, semiconductors, and networking firms), (2) the medical-related and research industries, and (3) the manufacturing industry.

A closer examination of the firms that do not conform to the industrydominant model offers additional empirical support for dominant industry models. Table 2.4 reveals that excluding the firms that are founded with any of the five basic models, the majority of firms are conceptually close to their industry's dominant model: the star model for the medical-related and research firms, and the engineering model for companies in all other industries in the sample, with the exception of manufacturing.

Nearly two-thirds of the firms ( 42 of 66) are within a single dimension of their industry's dominant model. The pattern is most pronounced in the electronics industry, in which the majority of firms not founded with one of the basic employment models are within one dimension of the dominant engineering model. Similarly, half of the firms in the medical or research industries 
Table 2.4

Distance from Dominant Employment Model by Industry Group

\begin{tabular}{lc|cc|cc}
\hline & \multicolumn{3}{c}{ Variant } & \multicolumn{2}{c}{ Deviant } \\
\hline & $\begin{array}{c}\text { INDUSTRY- } \\
\text { DOMINANT } \\
\text { MODEL }\end{array}$ & $\begin{array}{c}\text { OTHER } \\
\text { ARCHETYPAL } \\
\text { MODEL }\end{array}$ & $\begin{array}{c}\text { I DIMENSION } \\
\text { FROM DOMINANT } \\
\text { MODEL }\end{array}$ & $\begin{array}{c}\text { 2 DIMENSIONS } \\
\text { FROM DOMINANT } \\
\text { MODEL }\end{array}$ & $\begin{array}{c}\text { 3 DIMENSIONS } \\
\text { FROM DOMINANT } \\
\text { MODEL }\end{array}$ \\
\hline Electronics & $\begin{array}{c}\text { Engineering } \\
44\end{array}$ & 24 & 36 & 12 & 5 \\
$\begin{array}{l}\text { Medical-related } \\
\text { or Research }\end{array}$ & $\begin{array}{c}\text { Star } \\
11\end{array}$ & 7 & 4 & 2 & 2 \\
$\begin{array}{l}\text { Manufacturing } \\
\text { Commitment } \\
2\end{array}$ & 0 & 2 & 1 & 2 \\
TOTAL & 57 & 31 & 42 & 15 & 9 \\
\hline${ }^{2}$ Computer relared, Semiconductors, Networking, or Telecommunications & &
\end{tabular}

are conceptually close to the dominant star model. Just under half of the manufacturing firms are within a single dimension of the commitment model. Thus, there is empirical support for dominant organizational models within broadly defined industry categories.

These industry archetypes, prevalent in the SPEC sample, also have validity from rich descriptions provided by others who have analyzed these industries. For example, medical-related firms rely heavily on scientific achievement and thus have been described as being strongly influenced by science-oriented cultures (Latour and Woolgar 1986; Henderson and Cockburn 1994; Werth 1994). The organizational model of the computer industry, in which work is accomplished primarily in project teams, has been carefully chronicled by Kidder (1981) and Kunda (1992). Furthermore, the electronics industry, particularly the Silicon Valley electronics industry, has a distinctive and dominant cultural model that one commentator has described as the "triumph of the nerds" (Cringely 1996, 17). Some of the commonly described features of this Silicon Valley organizing mode include relatively flat organizational structures, incentive systems that encourage (rather than penalize) risktaking, and team-based projects that encourage communication and coordination (Sager 1997). The strong technology-oriented organizational cultures are purported to have loose organizational boundaries, weak organi- 
zation-to-employee relationships yet strong project (or task) affiliations, and status hierarchies that reflect technical ability (Saxenian 1994). Finally, highcommitment work systems, particularly for manufacturing organizations, were commonly described (and prescribed) by management gurus throughout much of the '80s and '90s (Applebaum and Batt 1994; Pfeffer 1994; Womack et al. 1990). Three factors may account for deviations from these dominant models: strategy, founding team characteristics, and external partners.

\section{Strategy}

Organizational scholars have asserted that human resource strategy (the employment model) and corporate strategy should be aligned (Lawrence and Lorsch 1967; Nadler and Tushman 1997; Schuler 1992; Sonnenfeld and Peiperl 1988; Pfeffer 1994). Both strategy and the employment model are core features of an organization that are established early in the life cycle, are difficult to reorient, and are among the foundational characteristics that shape future organizational evolution (Hannan and Freeman 1984; Romanelli and Tushman 1994). Prior research has documented the association between strategy and the employment model (Hannan, Burton, and Baron 1996); thus, it is both a theoretical and a logical extension to presume that within a given industry, some of the variation in employment models can be explained by differences in strategy.

The firms in the SPEC sample varied in their dominant strategic focus. SPEC researchers categorized initial strategies by content by analyzing interviews with founders, supplemented in some cases by other sources such as newspaper articles, industry analysts' reports, or business plans (see Hannan, Burton, and Baron 1996 for more information). Founders were asked in the interviews to report their firms' distinctive source of competitive advantage. From their responses firms could be grouped into four main categories: (1) innovator, (2) enhancer, (3) marketer or marketing hybrid, and (4) low-cost producer.

Innovator. Innovator firms seek competitive advantage through innovation or technological leadership. Such firms seek first-mover advantages by winning a technology race. The emphasis in these firms is on revolutionary technology, which often involves gaining a crucial patent or patents. Among firms in the SPEC study that could be classified according to the founder's human resource 
model, roughly $50 \%$ were coded as belonging in this category, which is hardly surprising given the high-tech industries involved.

Enhancer. Some firms set out to enhance existing technologies. These firms seek to produce a product or product line similar to those of other companies but make some general modification to the technology to gain competitive advantage. Distinctive competencies can include system integration (e.g., of software and hardware), superior quality (in terms of dependability or availability of features desired by customers), and the like. Just under $20 \%$ percent of the firms fell into the enhancer category.

Marketer. Some of the SPEC firms planned to compete on the basis of superior sales, marketing, or customer service. Firms in the marketer category seek competitive advantage by developing or capitalizing on superior relations with customers, achieved through custom design of products, nonstandard methods of sales or distribution, or simply by developing superior capabilities in marketing, sales, branding, and/or customer service. Often, this strategy entailed firms creating products in direct response to customers' idiosyncratic needs, frequently working interactively with customers toward that end. In the SPEC sample, $13.6 \%$ were classified as having strategies driven by marketing, sales, and/or service. For the purposes of this chapter, an additional $10.4 \%$ of the sample that reported combining a marketing-service focus with an emphasis either on enhancing an existing technology or on technological leadership is included. Thus, in the SPEC sample $24 \%$ of the firms can be considered marketers.

Low-cost producer. Firms that are low-cost producers seek cost advantages through superior production techniques, economies of scale, and the like. Only a small number of firms were classified as having a pure low-cost strategy, but several others combined an emphasis on cost minimization with some other focus (generally marketing or service) and were classified by the researchers into this category as well, resulting in a total of $7.1 \%$ of the companies.

As is evident in Table 2.5, among the firms in the SPEC sample, there is a strong association between industry and strategy, and much of the statistical association can be accounted for by the overrepresentation of medical-related firms pursuing an innovator strategy and manufacturing firms pursuing a low-cost strategy. Despite a strong association between industry and strategy, however, there is also a fair amount of strategic diversity. The computer- 
Table 2.5

Association Between Industry and Strategy Among SPEC Sample Firms

(cell counts and row percentages)

\begin{tabular}{lccccc}
\hline & Innovator & Enhancer & $\begin{array}{c}\text { Marketingl } \\
\text { Cybrid }\end{array}$ & Cost & Total \\
\hline Computer related & 36 & 16 & 14 & 6 & 72 \\
Semiconductor & $50.0 \%$ & $22.2 \%$ & $19.4 \%$ & $8.3 \%$ & $100.0 \%$ \\
& 8 & 4 & 4 & & 16 \\
Networking and & $50.0 \%$ & $25.0 \%$ & $25.0 \%$ & & $100.0 \%$ \\
Telecommunications & 11 & & & & \\
& $33.3 \%$ & $24.2 \%$ & $36.4 \%$ & $6.1 \%$ & $100.0 \%$ \\
Medical related & 18 & 1 & 3 & & 22 \\
& $81.8 \%$ & $4.5 \%$ & $13.6 \%$ & & $100.0 \%$ \\
Research & 3 & & 1 & & 4 \\
& $75.0 \%$ & & $25.0 \%$ & & $100.0 \%$ \\
Manufacturing & & 1 & 3 & 3 & 7 \\
& & $14.3 \%$ & $42.9 \%$ & $42.9 \%$ & $100.0 \%$ \\
Total & 76 & 30 & 37 & 11 & 154 \\
& $49.4 \%$ & $19.5 \%$ & $24.0 \%$ & $7.1 \%$ & $100.0 \%$ \\
\hline
\end{tabular}

NOTE: Pearson chi-square $=33.91$, d.f. $=15, p=.004$

related and networking and telecommunications industries have firms represented in all four strategy categories. The semiconductor, medical-related, and manufacturing industries have firms represented in three of the four strategy categories. It is only the research industry, the most sparsely represented industry, that exhibits limited strategic range.

As described above, most of the high-technology firms in the SPEC sample reported pursuing a technology-driven strategy, either enhancing existing technology or developing innovative new technology. These firms focus on product development rather than organizational development and thus should be most likely to conform to the dominant industry model. In contrast, those firms founded to compete on the basis of superior sales, marketing, or service, or on having lower costs rely on an organizational competence to achieve their strategic goals, which suggests that they will pay greater attention to organizational design and architecture. 
Hypothesis 1: Firms pursuing organizational as opposed to technological strategies will be more likely to deviate from the industry dominant model.

A preliminary test of this hypothesis can be done by cross-classifying strategy and initial employment model by industry, given that the associations between strategy and industry and between industry and employment model are strong (see Tables 2.3 and 2.5). A more fine-grained analysis revealed that the overall association between strategy and employment model is modest (chisquare $=22.75$, d.f. $=15, \mathrm{p}=.10$ ). Within industries, however, the association between strategy and employment model is nonexistent, producing no statistically significant associations (electronics: chi-square $=15.34$, d.f. $=15$, $\mathrm{p}=0.43$; medical: chi-square $=2.37$, d.f. $=6, \mathrm{p}=0.88$; manufacturing: chisquare $=3.73$, d.f. $=2, p=0.12$ ). This implies that there is a great deal of model variation to be explained by factors other than technical or strategic considerations, including characteristics of the founding team.

\section{Founding Team Characteristics}

There is a long-standing stream of research suggesting that organizational founders exert a powerful and lasting influence on the firms that they create (Boeker 1988; DiMaggio 1991; Eisenhardt and Schoonhoven 1990; Schein 1983). Furthermore, there is ample empirical evidence supporting the contention that top management team characteristics are powerful predictors of organizational features (Finkelstein and Hambrick 1996; Fligstein 1987). Obviously, prior experience is likely to be related to organization-building models (Cooper 1985). With experience comes knowledge of different organizational models as well as an appreciation for how employees fare under different alternatives. Archival sources, including newspaper and magazine articles, internal company documents, and published directories, were used to gather career history information for each founding team member. The career history data were used to identify three types of experience: prior founding experience, senior management experience, and nontechnical (sales, marketing, finance, or administrative) experience, all of which are likely to lead founders away from industry-dominant models. Senior management experience is defined as holding a title of vice president or higher prior to founding 
the focal firm. Prior founding experience is likely to be undercounted in these sources, however, since successful ventures tend to be mentioned in executive biographies whereas failures do not.

There are two mechanisms by which experience leads to deviance: confidence and exposure to alternatives. Experienced founders who have either founded a firm in the past and/or held senior executive positions have presumably had the benefit of operating under at least one model and may feel confident in their ability to construct or invent a model that suits them. By analogy, first-time parents are more likely to raise their child by the book than are experienced parents. Exposure to alternative models may also liberate founders to deviate from the industry norm. Founders with nontechnical backgrounds are more likely to have had experience in other industries and therefore will be less well socialized to the dominant industry model. Similarly, founders who have held senior management roles are likely to have held positions in multiple firms and thus may have experience with multiple employment models.

Hypothesis 2: Firms founded by experienced teams will be more likely to deviate from the industry dominant model.

Experience need not be embodied in a single founder but, rather, can be the aggregate experience of all members of the founding team. In the SPEC sample, the size and composition of the founding team, as well as how the team members came together, varied dramatically across the sample. Founding teams ranged in size from one to twelve. A relatively small fraction (15.9\%) were founded by a solo entrepreneur. The most typical SPEC firms were founded by two $(32.3 \%)$, three $(22.6 \%)$, or four $(14.6 \%)$ people. The remaining firms (14.6\%) were founded by teams of five or more. One of the most striking features of the founders in this sample is the diversity of experience. The majority of the firms had at least one member of the founding team with technical experience (76.2\%). Just over half of the firms (55.4\%) had at least one team member who had earlier held a senior management position (vice president or higher) in another company. Roughly one-third of the firms $(36.9 \%)$ had at least one founder who had prior start-up experience. Fewer than one-third of the firms had a founder with experience in either sales $(29.8 \%)$ or finance $(10.7 \%)$. 


\section{External Partners}

It is often asserted that interorganizational relationships are important determinants of organizational characteristics (e.g., Haunschild 1994). Firms scan the environment and adopt organizational features that others have adopted. This process of organizational imitation is accelerated when there are network ties linking firms (DiMaggio and Powell 1983). While most of the empirical research on this topic has assessed the diffusion of organizational structures and practices, it is reasonable to assume that the same processes operate in the diffusion of employment models. Furthermore, the influence of significant others is likely to be dramatic in very young firms, given their lack of legitimacy and need for resources (Nohria 1992). External partners, such as venture capitalists, who help bring cash to new firms, may be important influences on the structure of new firms (Suchman 1994).

Hypothesis 3: Firms whose important external partners include venture capitalists will be less likely to deviate from the dominant industry model.

As described above, founders were asked in a written survey about the external partners and advisors who were involved in the founding. The survey item asked the respondent to list "important actors and the roles they played in the founding process." Beyond listing the members of the founding team, respondents identified 12 types of external partners: four types of investors (venture capitalists, private investors, corporate investors, other), lawyers, accountants, board members, customers, employees, friends or family, previous employers, and other advisors. The frequencies of different types of external partners are reported in Table 2.6.

In Table 2.6, partners have been aggregated for each firm so that each type of partnership variable has a discrete yes-or-no value. In other words, the variables simply indicate whether the founder mentioned any individuals who fulfilled a particular role. ${ }^{4}$ While lawyer, board member, and venture capitalist are the most frequently mentioned categories of external partnership, each was

4. This coding does not account for either multiple roles by a single individual, such as a venture capitalist who is also an advisor and a board member, or for multiple individuals playing a single role, as is the case when a respondent listed several private investors. 
Table 2.6

Frequency of Different Types of

External Partners Among SPEC Sample Firms

\begin{tabular}{lcr}
\hline Partner Role & Number of Firms & Percent of Firms \\
\hline Investors & 89 & $77.4 \%$ \\
Venture capital & 59 & $51.3 \%$ \\
Private & 30 & $26.1 \%$ \\
Corporate & 23 & $20.0 \%$ \\
Other & 3 & $2.6 \%$ \\
Lawyers & 62 & $53.9 \%$ \\
Board members & 59 & $51.3 \%$ \\
Advisors & 57 & $49.6 \%$ \\
Accountants & 15 & $13.0 \%$ \\
Customers & 13 & $11.3 \%$ \\
Employees & 11 & $9.6 \%$ \\
Friends and family & 6 & $5.2 \%$ \\
Previous employer & 5 & $4.3 \%$ \\
\hline
\end{tabular}

listed by just over half of the firms $(53.9 \%, 51.3 \%$, and $51.3 \%$ of the firms, respectively). Similarly, advisors were mentioned by $49.6 \%$ of the firms. Other types of partners were mentioned less frequently. It is worth noting that partnership types seem to cluster. A simple similarity ratio computed from a correlation-type matrix reveals that venture capitalist, lawyer, advisor, and board member tend to be co-present. ${ }^{5}$

\section{ANALYSES}

Multinomial logistic regression analyses were used to examine conformity to and deviance from the dominant industry model. The empirical strategy distinguishes, at one extreme, those firms that adopt their industry's model and, at the other extreme, those firms that are not adopting any of the five basic employment models (nor anything conceptually close to any of the five basic

5. This analysis used a Jaccard measure for binary variables. This is an index based on a $2 \times 2$ table of variable 1 (present, absent) crossed by variable 2 (present, absent). In the Jaccard measure, joint absences are excluded from consideration and equal weight is given to matches and nonmatches. 
types) and are two or more dimensions from the dominant industry model. The intermediate category, described as variants, includes the firms that are founded under a basic employment model or are within one dimension of the dominant industry model. This empirical strategy was driven by an interest in identifying the sources of novel organizational forms, which occurs when firms are founded with extremely deviant employment models. The analytic strategy allows novelty (deviance) to be distinguished empirically from wellunderstood archetypal employment models or models that are conceptually close to such models. Industry-dummy variables were included to control for the different strengths of the industry-specific dominant models. As shown above, the greatest propensity to conform to an industry template was evident in the electronics industry, while firms in the medical-related industry were most likely to be founded with a basic (or near) star model. A substantial number of firms were organized with an engineering model. In contrast, the only basic model that is apparent in the SPEC manufacturing firms is the commitment model. Furthermore, the firms founded with nonbasic models are more likely to be distant from the commitment model (three firms are two or more dimensions from commitment) than they are to be close to it (two firms are only one dimension from commitment).

To account for two potential sources of heterogeneity-initial scale and idiosyncratic time variations from things like short-term labor market fluctuations - we included a measure of the firm size (the natural logarithm of the number of employees at the end of the first year of operations) and the age of the firm when we first interviewed the founder.

\section{RESULTS}

Table 2.7 presents the results of a multinomial logistic regression predicting the initial employment model. The baseline (omitted) category is for firms conforming to their industry's dominant model. The two panels in the table represent the varying degrees of deviance from the normative prescription. The first panel represents the most extreme deviance, in which firms adopt a model that is conceptually distant from both the dominant model and the four alternative archetypes. The second panel represents variants, more modest devia- 
Table 2.7

Multinomial Logistic Regression Predicting Deviation from Industry-Dominant Model $(\mathrm{N}=123)$

(omitted category $=$ industry-dominant model)

\begin{tabular}{lcc}
\hline $\begin{array}{l}\text { Deviant: Model Is Two or More Dimensions } \\
\text { from the Industry-Dominant Model }\end{array}$ & $\begin{array}{c}\text { Model I } \\
\text { Cofficient } \\
\text { (standard error) }\end{array}$ & $\begin{array}{c}\text { Model 2 } \\
\text { Coefficient } \\
\text { (standard error) }\end{array}$ \\
\hline Initial organizational size & -0.19 & -0.69 \\
Age & $(0.42)$ & $(0.52)$ \\
Medical or research industry & $-0.32+$ & -0.27 \\
Manufacturing industry & $(0.20)$ & $(0.20)$ \\
Nontechnology strategy & 0.73 & 0.82 \\
& $(1.35)$ & $(1.66)$ \\
Number of founders & 1.15 & $3.21^{b}$ \\
& $(1.21)$ & $(1.64)$ \\
Number of founders with & $3.22^{c}$ & $3.79^{c}$ \\
finance, sales, or marketing experience & $(1.22)$ & $(1.56)$ \\
Number of founders with & & -1.09 \\
senior management experience & & $(0.68)$ \\
Constant & & $1.50^{a}$ \\
& & $(0.81)$ \\
& & $1.39^{b}$ \\
& & $(0.68)$ \\
& & -1.27 \\
& $(1.92)$ & $(2.29)$ \\
\hline
\end{tabular}

(continued)

tions, in which the founders have avoided the dominant model but have adopted a model that is (or is close to) one of the four archetypes. Model 1 includes only technical and environmental determinants of the employment model. Model 2 adds characteristics of the founding team. The results indicate that much of the tendency toward nonstandard employment models can be explained by differences in strategy, supporting hypothesis 1 . This is particularly true when the firm dramatically deviates from the industry's dominant model.

An interesting and unanticipated finding is that, controlling for functional 
Table 2.7 (continued)

\begin{tabular}{lcc}
\hline $\begin{array}{l}\text { Variant: One of the Four Other Archetypal } \\
\text { Models or Within One Dimension of the }\end{array}$ & $\begin{array}{c}\text { Model 1 } \\
\text { Coefficient } \\
\text { (standard error) }\end{array}$ & $\begin{array}{c}\text { Model } 2 \\
\text { Coefficient } \\
\text { (standard error) }\end{array}$ \\
\hline Initial organizational size & -0.19 & -0.15 \\
Age & $(0.19)$ & $(0.21)$ \\
Medical or research industry & 0.05 & 0.06 \\
& $(0.07)$ & $(0.08)$ \\
Manufacturing industry & -0.75 & -0.67 \\
Nontechnology strategy & $(0.52)$ & $(0.55)$ \\
Number of founders & -0.94 & -0.76 \\
& $(1.07)$ & $(1.08)$ \\
Number of founders with & 0.38 & 0.23 \\
finance, sales, or marketing experience & $(0.49)$ & $(0.50)$ \\
Number of founders with & & $-0.25^{b}$ \\
senior management experience & & $(0.12)$ \\
Constant & & 0.33 \\
Model chi-square & & $(0.28)$ \\
Degrees of freedom & & 0.05 \\
\hline
\end{tabular}

NOTE: $+\mathrm{p}<.15 ;{ }^{\mathrm{a}} \mathrm{p}<.10 ;{ }^{\mathrm{b}} \mathrm{p}<.05 ;{ }^{\mathrm{c}} \mathrm{p}<.01$

heterogeneity, larger teams are less likely to deviate from the dominant industry model. This coefficient is a statistically significant predictor of modest deviations and is close to being statistically significant $(p=0.11)$ for more dramatic deviations. One plausible explanation for these findings is rooted in group dynamics. Developing an initial employment model in a group setting may require that all parties converge. It is highly likely that through a process of consensus building and compromising, the emergent model will closely resemble a dominant industry model.

The most intriguing finding is that there are key experience differences 
among those founding teams whose initial employment model differs dramatically from the industry archetype. Founding teams with more senior management experience and more nontechnical experience (controlling for the total number of founders) are the most likely to deviate from the dominant industry model, net of strategic considerations, supporting hypothesis 2 . In other words, experienced executives who are part of a functionally wellrounded founding team are the most likely to adopt an employment model that is different from either the dominant industry model or any other wellunderstood cultural archetype. An interpretation of this finding is that those firms that begin with functionally heterogeneous teams do so because they differ in the complexity or diversity of their operations. This diversity may have implications for which model is most appropriate, and it may require deviating from an industry's dominant model. An alternative explanation for the finding is that it is driven by the presence of industry outsiders. Comparing two founding teams of the same size, a team that includes broad business experience (senior management, finance, sales, or marketing) has a higher probability of drawing on industry outsiders than one of primarily technical founders. An interesting topic for future research is determining the consequences of adopting a novel model.

In other analyses of the survey data, I tested hypothesis 3, on the role of external partners, such as lawyers and venture capitalists. As Table 2.8 shows, although there are bivariate associations between having a venture capitalist as an important partner and adopting a particular employment model, in multivariate analyses that included dummy variables to indicate whether either a lawyer or a venture capitalist was listed as a partner, neither coefficient was statistically significant. Furthermore, including the variables did not change the results described above. I omit them from the reported results because they decrease the usable sample ( 54 cases are dropped due to missing partner data).

One possible explanation of the lack of effect for the influence of external partners is that, as posited above, the salience of particular external actors may vary both by industry and by strategy. It is also possible that external influences are not directly in the form of partner relationships but, rather, are indirect, coming through more subtle mechanisms such as executive migration (Boeker 1997) or broader field-level conflicts and contests (Ventresca and Washington 
Table 2.8

Association Between External Influences and Employment Model

\begin{tabular}{|c|c|c|c|c|c|c|c|}
\hline Partner & $\begin{array}{c}\text { Autocracy } \\
N=7 \\
(6.3 \%)\end{array}$ & $\begin{array}{c}\text { Commitment } \\
\quad N=12 \\
(10.7 \%)\end{array}$ & $\begin{array}{c}\text { Star } \\
N=13 \\
(11.6 \%)\end{array}$ & $\begin{array}{c}\text { Engineering } \\
\quad N=41 \\
(36.6 \%)\end{array}$ & $\begin{array}{c}\text { Bureaucracy } \\
\quad N=5 \\
(4.5 \%)\end{array}$ & $\begin{array}{c}\text { Other } \quad L \\
N=34 \\
(30.4 \%)\end{array}$ & $\begin{array}{c}\text { Likelihood Ratio } \\
\text { Chi-square } \\
\text { (5 d.f.) }\end{array}$ \\
\hline $\begin{array}{l}\text { Private investor } \\
\qquad(\mathrm{N}=30)\end{array}$ & $\begin{array}{c}1 \\
(3.4 \%)\end{array}$ & $\begin{array}{c}3 \\
(10.3 \%)\end{array}$ & $\begin{array}{c}6 \\
(20.7 \%)\end{array}$ & $\begin{array}{c}10 \\
(34.5 \%)\end{array}$ & $\begin{array}{c}0 \\
(0.0 \%)\end{array}$ & $\begin{array}{c}9 \\
(31.0 \%)\end{array}$ & 6.08 \\
\hline $\begin{array}{l}\text { Venture capitalist } \\
\qquad(N=59)\end{array}$ & $\begin{array}{c}2 \\
(3.4 \%)\end{array}$ & $\begin{array}{c}4 \\
(6.9 \%)\end{array}$ & $\begin{array}{c}7 \\
(12.1 \%)\end{array}$ & $\begin{array}{c}23 \\
(39.7 \%)\end{array}$ & $\begin{array}{c}5 \\
(8.6 \%)\end{array}$ & $\begin{array}{c}17 \\
(29.3 \%)\end{array}$ & $10.16^{a}$ \\
\hline $\begin{array}{l}\text { Corporate investor } \\
\qquad(\mathrm{N}=23)\end{array}$ & $\begin{array}{c}2 \\
(9.1 \%)\end{array}$ & $\begin{array}{c}2 \\
(9.1 \%)\end{array}$ & $\begin{array}{c}3 \\
(13.6 \%)\end{array}$ & $\begin{array}{c}9 \\
(40.9 \%)\end{array}$ & $\begin{array}{c}2 \\
(9.1 \%)\end{array}$ & $\begin{array}{c}4 \\
(18.2 \%)\end{array}$ & 3.22 \\
\hline $\begin{array}{l}\text { Other investor } \\
\qquad(N=3)\end{array}$ & $\begin{array}{c}1 \\
(33.3 \%)\end{array}$ & $\begin{array}{c}1 \\
(33.3 \%)\end{array}$ & $\begin{array}{c}0 \\
(0.0 \%)\end{array}$ & $\begin{array}{c}0 \\
(0.0 \%)\end{array}$ & $\begin{array}{c}0 \\
(0.0 \%)\end{array}$ & $\begin{array}{c}1 \\
(33.3 \%)\end{array}$ & 5.99 \\
\hline $\begin{array}{l}\text { Lawyer } \\
\qquad(\mathrm{N}=62)\end{array}$ & $\begin{array}{c}2 \\
(3.3 \%)\end{array}$ & $\begin{array}{c}3 \\
(5.0 \%)\end{array}$ & $\begin{array}{c}6 \\
(10.0 \%)\end{array}$ & $\begin{array}{c}25 \\
(41.7 \%)\end{array}$ & $\begin{array}{c}4 \\
(6.7 \%)\end{array}$ & $\begin{array}{c}20 \\
(33.3 \%)\end{array}$ & 8.96 \\
\hline $\begin{array}{l}\text { Advisor } \\
\qquad(\mathrm{N}=57)\end{array}$ & $\begin{array}{c}1 \\
(1.9 \%)\end{array}$ & $\begin{array}{c}5 \\
(9.4 \%)\end{array}$ & $\begin{array}{c}7 \\
(12.5 \%)\end{array}$ & $\begin{array}{c}25 \\
(44.6 \%)\end{array}$ & $\begin{array}{c}4 \\
(7.1 \%)\end{array}$ & $\begin{array}{c}14 \\
(25.0 \%)\end{array}$ & $9.36^{a}$ \\
\hline $\begin{array}{l}\text { Accountant } \\
(N=15)\end{array}$ & $\begin{array}{c}1 \\
(7.1 \%)\end{array}$ & $\begin{array}{c}2 \\
(14.3 \%)\end{array}$ & $\begin{array}{c}1 \\
(7.1 \%)\end{array}$ & $\begin{array}{c}6 \\
(42.9 \%)\end{array}$ & $\begin{array}{c}0 \\
(0.0 \%)\end{array}$ & $\begin{array}{c}4 \\
(28.6 \%)\end{array}$ & 2.02 \\
\hline $\begin{array}{l}\text { Board member } \\
\qquad(\mathrm{N}=59)\end{array}$ & $\begin{array}{c}5 \\
(8.5 \%)\end{array}$ & $\begin{array}{c}8 \\
(13.6 \%)\end{array}$ & $\begin{array}{c}4 \\
(6.8 \%)\end{array}$ & $\begin{array}{c}24 \\
(40.7 \%)\end{array}$ & $\begin{array}{c}2 \\
(3.4 \%)\end{array}$ & $\begin{array}{c}16 \\
(39.0 \%)\end{array}$ & 5.86 \\
\hline $\begin{array}{l}\text { Customer } \\
\qquad(N=13)\end{array}$ & $\begin{array}{c}1 \\
(7.7 \%)\end{array}$ & $\begin{array}{c}1 \\
(7.7 \%)\end{array}$ & $\begin{array}{c}0 \\
(0.0 \%)\end{array}$ & $\begin{array}{c}6 \\
(46.2 \%)\end{array}$ & $\begin{array}{c}1 \\
(7.7 \%)\end{array}$ & $\begin{array}{c}4 \\
(30.8 \%)\end{array}$ & 4.02 \\
\hline $\begin{array}{l}\text { Founder } \\
\qquad(\mathrm{N}=34)\end{array}$ & $\begin{array}{c}3 \\
(9.1 \%)\end{array}$ & $\begin{array}{c}6 \\
(18.2 \%)\end{array}$ & $\begin{array}{c}3 \\
(9.1 \%)\end{array}$ & $\begin{array}{c}12 \\
(36.4 \%)\end{array}$ & $\begin{array}{c}0 \\
(0.0 \%)\end{array}$ & $\begin{array}{c}9 \\
(27.3 \%)\end{array}$ & 6.69 \\
\hline $\begin{array}{l}\text { Employee } \\
\qquad(N=11)\end{array}$ & $\begin{array}{c}0 \\
(0.0 \%)\end{array}$ & $\begin{array}{c}0 \\
(0.0 \%)\end{array}$ & $\begin{array}{c}2 \\
(18.2 \%)\end{array}$ & $\begin{array}{c}5 \\
(45.5 \%)\end{array}$ & $\begin{array}{c}0 \\
(0.0 \%)\end{array}$ & $\begin{array}{c}4 \\
(36.4 \%)\end{array}$ & 5.74 \\
\hline $\begin{array}{l}\text { Kin } \\
\qquad(N=6)\end{array}$ & $\begin{array}{c}1 \\
(16.7 \%)\end{array}$ & $\begin{array}{c}3 \\
(50.0 \%)\end{array}$ & $\begin{array}{c}0 \\
(0.0 \%)\end{array}$ & $\begin{array}{c}1 \\
(16.7 \%)\end{array}$ & $\begin{array}{c}0 \\
(0.0 \%)\end{array}$ & $\begin{array}{c}1 \\
(16.7 \%)\end{array}$ & $9.13^{a}$ \\
\hline $\begin{array}{l}\text { Previous company } \\
\qquad(\mathrm{N}=5)\end{array}$ & $\begin{array}{c}0 \\
(0.0 \%)\end{array}$ & $\begin{array}{c}0 \\
(0.0 \%)\end{array}$ & $\begin{array}{c}1 \\
(25.0 \%)\end{array}$ & $\begin{array}{c}2 \\
(50.0 \%)\end{array}$ & $\begin{array}{c}0 \\
(0.0 \%)\end{array}$ & $\begin{array}{c}1 \\
(25.0 \%)\end{array}$ & 2.46 \\
\hline
\end{tabular}

NOTE: ${ }^{\mathrm{a}} \mathrm{p}<10$

1998). Another interesting possibility is that external partnerships may be most important when founders lack experience or legitimacy, as do founders who are young scientists or engineers. These founders are most likely to adopt an industry dominant model and are least likely to have venture backing. The process of choosing that model may or may not be related to the influence of external partners. 


\section{DISCUSSION}

This research raises two broad issues related to organizational models and entrepreneurship. First, treatments of entrepreneurial strategy have tended to focus exclusively on the product or financing domains. If we are to take seriously the organization-building side of entrepreneurial strategy, however, we must consider both the options available to entrepreneurs (e.g., the labor markets in which they compete) and the available models for organizing. Second, understanding strategic organization-building choices may require alternative conceptualizations.

This research concentrates on models used by entrepreneurs to guide the ways in which they build their firms. There is evidence that dominant models of the employment relationship vary among industries, even within the relatively homogenous high-technology sector. There is also strong evidence of considerable variation around the dominant models. This chapter begins to explore the sources of variation in the models. The evidence presented here indicates that strategy matters: firms pursuing a nontechnology strategy are more likely to deviate from the dominant industry model than are firms that are pursuing a more purely technical path. Further, the demographic composition of the founding team makes a difference. Smaller founding teams are more likely to deviate from an industry-dominant model as are teams whose members have backgrounds in finance, sales, or marketing or that include founders with senior-level management experience.

At a minimum, the findings reported here suggest that broad interpretations of institutional theory particularly, and organizational theory more generally, may systematically underestimate the patterned variation in organizational models present in a given field. Entrepreneurs do not appear to be overly constrained by overarching cultural pressures, as represented in institutional theory, or by the expectations of those people and other firms on whom they depend, as in resource dependence theory, or by the technical requirements of the task. Rather, entrepreneurs with broader business experience may in fact devise novel organizational forms that resonate with particular business strategies or that are consistent with their own personal values (DiMaggio 1991; Fombrun 1988).

A second issue raised by this research concerns the strategic use of models 
of the employment relation. Deviant employment models may be mistakes, and they may result from founders being disconnected, but they do not appear to stem from a lack of experience. Instead, it appears that novel employment models are tolerated when the founding team has extensive experience, both across functions and at the highest level of organizations. It is these seasoned professionals who are credibly able to devise their own employment model.

The second alternative is that nonstandard employment models reflect deliberate strategic choices by entrepreneurs trying to differentiate their firm in the labor market. Although this explanation finds some support here, the factors appear to be more complex than is typically imagined (e.g., Sonnenfeld and Peiperl 1988). The interviews with founders revealed clearly that some entrepreneurs truly operated in default mode in building their organizations, reporting that they didn't give any attention to such issues. Other founders reported that they operated quite deliberately in choosing models of the employment relation and in initial organization building. Among the latter were two types. Some founders chose models for ideological reasons; they reported strong beliefs in the intrinsic value of the models they implemented and made no reference to performance implications or consequences. Others reported that their choice of model was based on business rationales about which models can attract key personnel in the current labor market or about the link between model and product strategy, with an eye toward improving the organizations' competitive chances or enhancing performance. Table 2.9 provides some illustrative quotes for each of these approaches.

The co-existence of these three modes of choosing models has potentially important consequences that have not yet been explored. For example, these different modes may influence the amount of diversity in the community of organizations. The default mode will tend to reproduce the dominant industry mode, especially when new ventures are guided by relatively large teams of technical founders. Such a process will produce stability over time within industries and maintain differences between industries, particularly when there is little cross-industry mobility among executives. The ideological mode would likely increase the variance within industries. The interviews revealed a strong oppositional component in the ideological mode: entrepreneurs expressed considerable distaste for the models used in the firms with which they had experience and a desire to create an organization that was the polar 
Table 2.9

\section{Sample Statements Illustrating Different Approaches to Choosing an Employment Model}

UnintendedIDefault
We did not really spend a lot of
time on organization. Not be-
cause it's not important, but
because you are in survival mode
and it's like a platoon, it's not an
army. You're thinking like a pla-
toon, you're a command opera-
tion, and you know that you
are, and you don't worry about
it, because you're not an army.
So don't try to be like an army,
because you'll be a very lousy
platoon. (19)

The culture was a de facto culture of hard work and long hours. Not much of a culture. (3)

Absolutely zero plan [for the employment relationship]. The biggest things on our minds were customers and products. We started paying deeper attention when we crossed the 50people barrier. (110)
The initial plan or blueprint was to be different than the typical Silicon Valley company. We were not looking to establish a "get rich quick" company. We wanted to follow an Eastern model of treating people well. And we didn't want to grow at the expense of our people. (1)

We wanted a strong participatory culture with an enormous amount of ground up information, not only from the management team, but also the people on the floor. (23)

I wanted to build a company that walked its talk. A company that mistreats its suppliers, for instance, but says it treats its customers well is lying. You have to build partners inside and build partners for your suppliers and partners for your customers. You can't do that if the basic culture of the company is "I just want to get rich and screw you." And what I've just described is probably closer to the Silicon Valley norm. (132)
The two key determinants of early success for biotechnology companies are science and capi$\mathrm{tal}$. The best scientists attract investors and capital, and capital attracts good scientists. The two complement and enforce each other, and you need both to succeed. That's it. Inadequate funding leads to bad science because you can't attract the best people. You won't attract or retain the best people because they can go somewhere that has the money, and they will. Secondly, when you start without the money, you start cutting corners. You have no choice. That ultimately comes back to bite you in the rear end. (104)

We know our size, our name, our business won't attract any top-notch people. So you have to use your relationships. People who know you can be successful. They believe in you more than they believe in the business. (39)

Basically, to work for us you have to be really, really good and you have to be willing to work for pretty much nothing. That eliminates all but the fanatics. People who come in here to work for us get lots of advantages. Mostly we hire engineers, people who make products. The ability to come in and write a product from the ground up that's your baby, and that's going to sell, and you'll have influence all the way through, from the design to artwork to packaging to distribution, is rare. (164) 
opposite. Such a mode will tend to increase the variance of organizational models within industries, assuming that entrepreneurs tend to remain within the same industries. The strategic mode is also likely to increase variability within industries. The most interesting case involves the strategic choice of organizational models directed toward attaining a distinctive position in the labor market. If entrepreneurs follow this logic, they will tend to move away from the dominant industry models and thereby increase the variance in models within industries.

Within the academy, there is strong consensus that organizational diversity is important and valuable. The value of heterogeneous organizational forms has been linked to public policy (Van de Ven and Garud 1989), industry dynamics (Delacroix, Swaminathan, and Solt 1989), organizational viability (Hannan and Freeman 1989), and individual career mobility (Carroll, Haveman, and Swaminathan 1992; Hannan 1988). Yet despite this consensus, there is still relatively little research that addresses the sources of organizational diversity. In this small sample of technology start-ups in Silicon Valley there is startling variation in founders' employment models, even among start-up companies in the same industry, competing directly against one another. This chapter is only a first step toward understanding the factors that create this diversity. There is still much work to be done. 